\title{
An Investigation into the Use of Cohesive Devises in Iranian High School EFL Textbooks
}

\author{
Mansour Shabani \\ English Language Department, University of Guilan, Iran \\ E-mail: mansour_shabani225@yahoo.com \\ Maryam Danaye Tous \\ English Language Department, University of Guilan, Iran \\ E-mail: maryam.dana@gmail.com \\ Leila Berehlia (Corresponding author) \\ University Campus 2, University of Guilan, Iran \\ E-mail: 1.berehlia@yahoo.com
}

Received: 13-11- 2014

Published: 01-07- 2015
Accepted: 25-01- 2015

doi:10.7575/aiac.ijalel.v.4n.4p.36
Advance Access Published: February 2015

URL: http://dx.doi.org/10.7575/aiac.ijalel.v.4n.4p.36

\begin{abstract}
The present study aimed at probing into the use of grammatical and lexical cohesive subdevices in Iranian high school EFL textbooks. To this end, the reading sections of three high school EFL textbooks and one pre-university EFL textbook were analyzed in terms of the distribution of grammatical and lexical cohesive subdevices. The results of Oneway ANOVA illustrated that: a)there are no significant differences among the frequencies of grammatical cohesive subdevices across grade 1 high school EFL textbook and the pre-university EFL textbook, b)there are significant differences among the frequencies of grammatical cohesive subdevices across grades 2 and 3 high school EFL textbooks. Moreover, the results of Chi-Square test showed that the significant values of all of the lexical cohesive subdevices were higher than .05 across each of the Iranian EFL high school textbooks. These findings can be beneficial for textbook writers, materials developers and EFL teachers.
\end{abstract}

Keywords: EFL textbook; cohesion; grammatical cohesion; lexical cohesion

\section{Introduction}

Learning English, as the medium of communication in todays' globalized world, is of great importance for many people. In Iran, English is taught as a foreign language (EFL). Dudly-Evans and ST. John (2005, p.35) believed that in some countries like Iran, all tertiary education is taught in the L1 with English being an auxiliary language. In this educational system, English is taught to the students from elementary school up to university level.

The English syllabus in the formal educational system of Iran is text-based. Feez and Joyce (2002) mentioned that a text-based syllabus is concerned with units of discourse called text. Text refers to any stretch of language held together cohesively by through meaning.

As McDonough, Shaw, and Masuhara (2013) stated, in recent years, the notion of discourse has been developed in human communication. Essentially, this notion provides the possibility of showing how various parts of a text or conversation or any stretch of language are interlinked or interwoven. This is done, for instance, by cross-referencing with the use of definite articles or pronouns, by markers of logical development (however, therefore, so, because and the like), by semantic links across items of vocabulary, by ellipsis in conversation (the short answers of textbook practice) and by substitution. This is usually referred to as the concept of cohesion; whereby relationships between different elements in a text- written or spoken -are made explicit. In other words, cohesion can be regarded as is a textual quality attained through the use of grammatical and lexical elements that enable readers to perceive or understand semantic relationships existing both within and between sentences (ibid.). Grammatical cohesion concerns such matters such as reference, ellipsis, substitution, and conjunction. In addition, lexical cohesion deals with sense relations such as synonymy, antonymy, metonymy, collocation, repetition, etc. According to Halliday and Hassan (1976), cohesion is "a semantic concept that occurs when the interpretation of some elements in the discourse is dependent on that of another" (p.4).

According to Brown (2001) textbooks constitute the most obvious and common form of material support for language teaching. The Iranian EFL high school textbooks are developed by the Ministry of Education and these textbooks play a key role in high school EFL education in the Iranian EFL context. In addition, based on Richards and Renandya (2001) the role of grammar is perhaps one of the most controversial issues in language teaching. So, analyzing the frequencies of grammatical and lexical cohesive devices can pave the way for realizing the strengths and weaknesses of the four Iranian EFL high school textbooks. Such attentions aim to satisfy the needs and wants of an idealized group of target 
learners who share similar needs and levels of proficiency. There are different studies conducted on various sorts of textbooks in Iran. Most studies on cohesive devices have focused on Persian literature, poetry, chemistry and Islamic textbooks. For example, Roshan and Armioon (2007) examined some university textbooks, and found out that lexical cohesion is mostly found in chemistry textbooks. Another related work has been done by Aghagolzadeh (2002) on mystical literature, philosophy and scientific books. He deduced that scientific books have the least number of lexical cohesive devices compared to philosophy and mystical books. Astaraki (2000; cited in Roshan \& Armioon, 2007) has also conducted a survey on cohesive devices of children and adult's books. In this study it was revealed that most cohesive devices were found in adult's textbooks.

In spite of the existence of some studied dealing with cohesion in textbooks, there are a few studies focusing on the use of cohesive devices in high school EFL textbooks. Therefore, the present study seeks to investigate cohesive devices utilized in Iranian high school EFL textbooks, and it attempts to find answers to the following research questions:

RQ1: Are there any significant differences among the frequencies of the use of grammatical cohesive subdevices across each EFL high school textbook?

RQ2. Are there any significant differences among the frequencies of the use of lexical cohesive subdevices across each EFL high school textbook?

Considering the aforementioned research questions, the following null hypotheses have been formulated:

$\mathrm{H}_{0}$ 1. There are no significant differences among the frequencies of the subdevices of grammatical cohesive devices across each EFL high school textbook.

$\mathrm{H}_{0}$ 2. There are no significant differences among the frequencies of the subdevices of lexical cohesive devices across each EFL high school textbook.

\section{Review of Literature}

Cohesion is part of the text forming component in the linguistic system. It is the means whereby elements that are structurally unrelated to one another are connected with each other. The resources that constitute the cohesive potential of a language are part of the total meaning potential of the language, and they have a kind of catalytic function since, without cohesion, the rest of the semantic system cannot be effectively activated in any sense (Halliday and Hassan, 1976).

The taxonomy of Halliday and Hasssan (1976) identifies two main grammatical and lexical cohesive devices which can be formally situated within a text. Grammatical cohesion has been regarded as the surface marking the semantic links between clauses and sentences in a written discourse, and between utterances and tunes in speech. These links can be of four types: reference, substitution, ellipsis, and conjunction. Reference is of three kinds: personal, demonstrative, and comparative reference, that each of them can be exophora, or endophora. Substitution has three main sub-parts: nominal, verbal and clausal. Ellipsis has also three main sub-parts, namely nominal, verbal and clausal ellipsis. Conjunction has five sub-parts: adversative, additive, temporal, causal, and continuative (ibid.).

Lexical cohesion refers to relationship between and among words in a text, and it is primarily related to sequence. The sequence of a text can be discovered through examining its content words. Sequences mostly have specialized vocabularies and tend to engage in specialized activities (Gerot \& Wignell, 1994; cited in Susilo, 2010). The lexical cohesion includes reiteration and collocation. Reiteration comprises repetition, synonym and near synonym, superordinate, and general word (Halliday and Hassan, 1976).

The literature on the use of cohesive devices, either grammatical or lexical, is so rich. In what follows a few research studies which have focused on cohesion will be reviewed.

Susilo (2010) investigated the grammatical and lexical cohesive devices of recount text in Look Ahead book. 'Look a Head' is an English textbook for 'tenth grade' published by Erlanga. As the textbook has a great role in teaching English and can be useful for foreign language learners, the investigator studied how the structure of the sentences in the paragraphs of each unit is. As cohesion could be helpful in making a linkage between the clauses and sentences of the text, and it could be an aid for better understanding of reading comprehension, the researcher put the number of cohesive devices in the form of percentage for all seven recount texts. The results showed that the average of grammatical cohesion was $59.86 \%$ and for lexical cohesion it was $72.88 \%$. According to Halliday and Hassan's (1976) study, $51 \%-75 \%$ is a good criterion. Thus the findings confirmed that this book is suitable for teaching English to foreign language learners.

Gholami, Ilghami, Molla Hossein, and Tahoori (2012) studied conjunctions, as one category of grammatical cohesive devices, in research papers on Biomedicine and Applied Linguistics written by Iranian authors. Their investigation revealed that although the researchers in both fields used conjunctions in sentence and non-sentence initial positions, Biomedical researchers used conjunctions more frequently than Applied Linguistics researchers. In addition, Biomedical researchers were more skillful in using conjunction devices in non- sentence initial positions.

In a further study, Rahi (2012) examined ellipsis as a type of grammatical cohesive device in English and Persian research articles. For this study, 10 articles in Persian and 10 papers in English were examined. The results showed that Persian and English have the same types of ellipsis; the only difference between them is quasi-ellipsis that was not found in Persian. The author suggested that English teachers have to emphasize the similarities and differences between Persian and English system of ellipsis. He further emphasized that the similarities between English and Persian ellipsis could result in EFL learners' making errors.

Moreover, Mohammadian (2013) investigated lexical cohesion in short stories of Sadegh Choobak, a prominent Iranian author. He found that repetition of the same word was used most frequently in these stories. Finally, Moghadam and Shabanipoor (2013) studied the application of ellipsis and lexical cohesion in the original dialogues of a television series, named 'Prison Break' with the Persian subtitled and dubbed versions of the same dialogues. They aimed to 
investigate the original dialogues of the film in terms of frequency of the use of lexical and ellipsis cohesive devices and compare these devices with the dubbed and subtitled versions, in order to find out the differences between these two types of translation (dubbing and subtitling) in terms of the use of lexical and ellipsis cohesive devices. The findings revealed that among lexical and grammatical cohesive devices, repetition and clausal ellipsis have been used most frequently in the original dialogues, respectively. It was also found that the two translated versions were similar in the use of lexical cohesive devices; however, the dubbed version had more ellipsis than the subtitled one.

\section{Methodology}

\subsection{Population and Sample}

The research population consisted of the 3 Iranian high school EFL textbooks plus 1 pre-university EFL textbook, each developed by the Iranian Organization for Education, Research, and Planning (Ministry of Education). In addition, the research sample consisted of the reading sections of the mentioned textbooks which were selected purposefully.

\subsection{Materials and Instruments}

Materials of this study were selected through the following procedures: First, the reading section of the 4 mentioned textbooks were selected, and then the number of words in each reading part was counted. The four textbooks were not homogeneous in terms of the number of words in their reading sections; in fact, the pre-university textbook contained 5197 words which is much more than the other three textbooks. In order to make the number of words homogeneous, the reading parts of the three lessons (lessons one, two, and six) of the pre-university textbook were randomly selected from among the eight lessons, along with all reading sections in the other three textbooks. Therefore, the materials utilized in the present study were as follows: Grade 1 high school EFL textbook consisted of nine lessons, each with one reading section containing 1964 words. Grade 2 high school EFL textbook consisted of seven lessons, each with one reading section containing 1685 words. Grade 3 high school EFL textbook included of six lessons, each with one reading section comprising 1825 words. And three lessons from the pre-university EFL textbook, each with one reading section made up of 1970 words.

The research instrument was a researcher-made checklist (Table1) developed based on Halliday and Hassan's (1976) categories of grammatical and lexical cohesive devices.

Table 1. Categories of grammatical and lexical cohesive devices and their subdevices

\begin{tabular}{cll}
\hline & Reference & Personal \\
& & Demonstrative \\
& Substitution & Comparative \\
& & Nominal \\
& Ellipsis & Verbal \\
& & Clausal \\
Grammatical & & Verbal \\
Cohesion & \multirow{3}{*}{ Conjunction } & Clausal \\
& & Adversative \\
& & Additive \\
& & Temporal \\
& & Causal \\
& Reiteration & Repetition \\
& & Synonym and Near Synonym \\
& & Superordinate \\
& & General Word \\
& & \\
\hline
\end{tabular}

\subsection{Data Collection Procedure}

The researcher collected the data through extracting the grammatical cohesive devices including references, substitutions, ellipsis, conjunctions and their subsets and the lexical cohesive devices including reiteration and its subsets and collocation from the reading sections of the four Iranian high school EFL textbooks. The grammatical cohesive devices contain reference and its subsets, i.e., three types of reference: personal, demonstrative, and comparative reference. Substitution has three main subsets: nominal, verbal and clausal. Ellipsis has three main subsets, too. They are nominal, verbal and clausal ellipsis. Conjunction also has four subsets: adversative, additive, temporal, causal, and continuative. Also, lexical cohesive devices contain reiteration and its subsets, i.e., repetition, synonym and near synonym, superordinate and general word. Collocation is another type of lexical cohesion.

Each sentence of the reading sections was divided into clauses and each subset of grammatical and lexical cohesive devices was examined in the whole selected texts.

In what follows one example from English book 1 is presented: 
That: demonstrative reference.

Time: collocation ever, lexical reference.

Greater: comparative reference.

Or: additive conjunction.

Wiser: comparative reference

Greater: collocation wiser, lexical cohesive.

Newton (mentioned in the preceding paragraph): repetition, reiteration, lexical cohesive.

But: adversative conjunction.

He: personal reference, anaphora.

Small things: general word, reiteration, lexical cohesive.

\subsection{Data Analysis}

Having determined the frequencies of grammatical and lexical cohesive devices, the research questions were answered using the descriptive statistics such as frequencies and percentages, as well as, inferential statistics including One-way ANOVA and Chi-square test. One-way ANOVA was used to determine whether there are any significant differences among the frequencies of the subdevices of grammatical cohesive devices across each of the four Iranian EFL high school textbooks. In addition, Chi-Square was used to investigate whether there are any significant differences among the frequencies of the subdevices of lexical cohesive devices across each of the four Iranian EFL high school textbooks.

\section{Results and Discussion}

The frequency of the use of the grammatical cohesive devices including reference, substitution, ellipsis, conjunction and lexical cohesive devices including reiteration and collocation counted in the reading sections of the four Iranian high school EFL textbooks are shown in Table 2.

Table 2. The frequency of the use of cohesive devices across the four Iranian EFL high school textbooks

\begin{tabular}{|c|c|c|c|c|c|c|}
\hline & & & Book & Book & Book & Book \\
\hline & & & 1 & 2 & 3 & 4 \\
\hline Grammatical & Reference & Personal & 183 & 171 & 117 & 195 \\
\hline Cohesion & & Demonstrative & 139 & 72 & 70 & 86 \\
\hline & & Comparative & 9 & 14 & 13 & 42 \\
\hline & Substitution & Nominal & 6 & 3 & 6 & 2 \\
\hline & & Verbal & 1 & 4 & 1 & 0 \\
\hline & & Clausal & 1 & 3 & 2 & 2 \\
\hline & Ellipsis & Nominal & 29 & 37 & 15 & 31 \\
\hline & & Verbal & 1 & 4 & 5 & 7 \\
\hline & & Clausal & 5 & 9 & 2 & 3 \\
\hline & Conjunction & Adversative & 17 & 14 & 12 & 9 \\
\hline & & Additive & 28 & 38 & 40 & 88 \\
\hline & & Temporal & 27 & 16 & 25 & 24 \\
\hline & & Causal & 7 & 7 & 10 & 8 \\
\hline & & Continuative & 1 & 0 & 0 & 0 \\
\hline Lexical & Reiteration & Repetition & 183 & 105 & 92 & 195 \\
\hline Cohesion & & Synonym and Near Synonym & 24 & 52 & 61 & 50 \\
\hline & & Superordinate & 15 & 27 & 27 & 11 \\
\hline & & General Word & 26 & 21 & 49 & 50 \\
\hline & Collocation & & 131 & 116 & 129 & 109 \\
\hline
\end{tabular}

In order to make the numbers of words in the reading sections of the four Iranian EFL high school textbooks more homogenous, the frequencies of the use of the subdevices of grammatical and lexical cohesive devices across each of the four Iranian EFL high school textbooks were calculated in percentages. For example, the frequency of the use of personal reference of the grammatical cohesive device in grade 1 high school EFL textbook is 183. According to the formula: $\frac{19 \mathrm{~s} 4}{100}=\frac{198}{\mathrm{X}} \quad \mathrm{X}=0.1$

The percentages of the use of the subdevices of grammatical and lexical cohesive devices across each of the four Iranian EFL high school textbooks are shown in Table 3: 
Table 3. The percentage of the use of cohesive devices across the four Iranian EFL high school textbooks

\begin{tabular}{|c|c|c|c|c|c|c|}
\hline \multirow{11}{*}{$\begin{array}{l}\text { Grammatical } \\
\text { Cohesion }\end{array}$} & \multirow{3}{*}{ Reference } & \multirow{3}{*}{$\begin{array}{l}\text { Personal } \\
\text { Demonstrative }\end{array}$} & \multirow{3}{*}{$\begin{array}{c}\text { Book } \\
\mathbf{1} \\
0.10 \\
0.14\end{array}$} & \multirow{3}{*}{$\begin{array}{c}\text { Book } \\
\mathbf{2} \\
0.09 \\
0.23\end{array}$} & \multirow{3}{*}{$\begin{array}{c}\text { Book 3 } \\
\\
0.15 \\
0.26\end{array}$} & \multirow{3}{*}{$\begin{array}{c}\text { Boo } \\
\mathbf{k} 4 \\
0.10 \\
0.22\end{array}$} \\
\hline & & & & & & \\
\hline & & & & & & \\
\hline & & Comparative & 2.18 & 1.20 & 1.40 & 0.46 \\
\hline & Substitution & Nominal & 3.27 & 5.61 & 3.04 & 9.85 \\
\hline & & Verbal & 19.64 & 4.21 & 18.25 & 0.00 \\
\hline & & Clausal & 19.64 & 5.61 & 9.12 & 9.85 \\
\hline & Ellipsis & Nominal & 0.67 & 0.45 & 1.21 & 0.63 \\
\hline & & Verbal & 19.64 & 4.21 & 3.65 & 2.81 \\
\hline & & Clausal & 3.92 & 1.87 & 9.12 & 6.56 \\
\hline & Conjunction & Adversative & 1.15 & 1.20 & 1.52 & 2.18 \\
\hline \multirow{9}{*}{$\begin{array}{l}\text { Lexical } \\
\text { Cohesion }\end{array}$} & \multirow{8}{*}{ Reiteration } & Additive & 0.70 & 0.44 & 0.45 & 0.22 \\
\hline & & Temporal & 0.72 & 1.05 & 0.73 & 0.82 \\
\hline & & Causal & 2.80 & 2.40 & 1.82 & 2.46 \\
\hline & & Continuative & 19.64 & 0.00 & 0.00 & 0.00 \\
\hline & & Repetition & 0.10 & 0.16 & 0.19 & 0.10 \\
\hline & & $\begin{array}{l}\text { Synonym and Near } \\
\text { Synonym }\end{array}$ & 0.81 & 0.32 & 0.29 & 0.39 \\
\hline & & Superordinate & 1.30 & 0.62 & 0.67 & 1.79 \\
\hline & & General Word & 0.75 & 0.80 & 0.37 & 0.39 \\
\hline & Collocation & & 0.14 & 0.14 & 0.14 & 0.18 \\
\hline
\end{tabular}

Table 4 shows the descriptive statistics of the use of the grammatical cohesive subdevices across grade 1 high school EFL textbook. This table presents the mean, standard deviation, and standard error of the means of subdevices of the grammatical cohesive devices.

Table 4. The results of the use of grammatical cohesive subdevices across grade 1 Iranian EFL high school textbook

\begin{tabular}{ccccc}
\hline & $\mathrm{N}$ & Mean & Std. Deviation & Std. Error \\
\hline Reference & 3 & .8067 & 1.18951 & .68676 \\
Substitution & 3 & 14.1833 & 9.45122 & 5.45667 \\
Ellipsis & 3 & 8.0767 & 10.14513 & 5.85729 \\
Conjunction & 5 & 5.0020 & 8.22801 & 3.67968 \\
Total & 14 & 6.7293 & 8.55036 & 2.28518 \\
\hline
\end{tabular}

Table 5 presents the results of ANOVA test:

Table 5. ANOVA results for grammatical cohesive subdevices across grade 1 Iranian EFL high school textbook

\begin{tabular}{|c|c|c|c|c|c|}
\hline & Sum of Squares & $D f$ & Mean Square & $F$ & Sig. \\
\hline Between Groups & 292.285 & 3 & 97.428 & 1.480 & .279 \\
\hline Within Groups & 658.129 & 10 & 65.813 & & \\
\hline Total & 950.413 & 13 & & & \\
\hline
\end{tabular}

Table 5 illustrates that there are not statistically significant differences among the four grammatical cohesive subdevices across grade 1 high school EFL textbook as determined by One-way ANOVA $(F(3,10)=1.48, p=.279)$. As indicated in the table, the $\mathrm{p}$-value is higher than our assumed alpha level $(p>.05)$.

Table 6 shows the descriptive statistics of the use of the grammatical cohesive subdevices across grade 2 high school EFL textbook.

Table 6. The results of the use of grammatical cohesive subdevices across grade 2 Iranian EFL high school textbook

\begin{tabular}{ccccc}
\hline & $\mathrm{N}$ & Mean & Std. Deviation & Std. Error \\
\hline Reference & 3 & .5067 & .60451 & .34901 \\
Substitution & 3 & 5.1433 & .80829 & .46667 \\
Ellipsis & 3 & 2.1767 & 1.89867 & 1.09620 \\
Conjunction & 5 & 1.0180 & .91029 & .40709 \\
$\quad$ Total & 14 & 2.0407 & 2.03405 & .54362 \\
\hline
\end{tabular}


Table 7 presents the results of ANOVA test:

Table 7. ANOVA results for grammatical cohesive subdevices across grade 2 Iranian EFL high school textbook

\begin{tabular}{|c|c|c|c|c|c|}
\hline & Sum of Squares & Df & Mean Square & $\mathrm{F}$ & Sig. \\
\hline Between Groups & 41.224 & 3 & 13.741 & 10.939 & .002 \\
\hline Within Groups & 12.562 & 10 & 1.256 & & \\
\hline Total & 53.786 & 13 & & & \\
\hline
\end{tabular}

Table 7 illustrates that there are statistically significant differences among the four grammatical cohesive subdevices across grade 2 high school EFL textbook $(F(3,10)=10.93, p=.002)$. As indicated in the table, $p$-value is less than alpha $(p<.05)$. In order to determine which specific groups differ, Tukey HSD test was run.

Table 8. Multiple comparison of Tukey HSD Test between grammatical cohesive subdevices across grade 2 Iranian EFL high school textbook

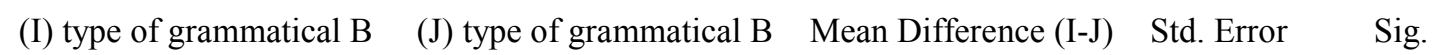

\begin{tabular}{ccccc}
\hline \multirow{2}{*}{ Reference } & Substitution & $-4.63667^{*}$ & .91513 & $\mathbf{. 0 0 2}$ \\
& Ellipsis & -1.67000 & .91513 & .318 \\
& Conjunction & -.51133 & .81852 & .922 \\
Substitution & Reference & $4.63667^{*}$ & .91513 & .002 \\
& Ellipsis & $2.96667^{*}$ & .91513 & $\mathbf{. 0 3 7}$ \\
& Conjunction & $4.12533^{*}$ & .81852 & $\mathbf{. 0 0 2}$ \\
\multirow{2}{*}{ Ellipsis } & Reference & 1.67000 & .91513 & .318 \\
& Substitution & $-2.96667^{*}$ & .91513 & $\mathbf{. 0 3 7}$ \\
& Conjunction & 1.15867 & .81852 & .518 \\
Conjunction & Reference & .51133 & .81852 & .922 \\
& Substitution & $-4.12533^{*}$ & .81852 & $\mathbf{. 0 0 2}$ \\
& Ellipsis & -1.15867 & .81852 & .518 \\
\hline
\end{tabular}

Table 8 shows the multiple comparisons of the grammatical cohesive subdevices across grade 2 high school EFL textbook. It indicates that the differences between reference and substitution $(p=.002)$, substitution and ellipsis ( $p=$ $.037)$, substitution and conjunction $(p=.002)$, ellipsis and substitution $(p=.037)$, and conjunction and substitution $(p=$ $.002)$, are statistically significant $(p<.05)$.

Table 9 shows the descriptive statistics of the use of the grammatical cohesive subdevices across grade 3 high school EFL textbook.

Table 9. The results of the use of grammatical cohesive subdevices across grade 3 Iranian EFL high school textbook

\begin{tabular}{lcccc}
\hline & $\mathrm{N}$ & Mean & Std. Deviation & Std. Error \\
\hline Reference & 3 & .6033 & .69212 & .39960 \\
Substitution & 3 & 10.1367 & 7.65580 & 4.42008 \\
Ellipsis & 3 & 4.6600 & 4.05057 & 2.33860 \\
Conjunction & 5 & .9040 & .75368 & .33705 \\
Total & 14 & 3.6229 & 5.17462 & 1.38297 \\
\hline
\end{tabular}

Table 10 presents the results of ANOVA test:

Table 10. ANOVA results for grammatical cohesive subdevices across grade 3 Iranian EFL high school textbook

\begin{tabular}{cccccc}
\hline \multicolumn{1}{c}{ Sum of Squares } & Df & Mean Square & F & Sig. \\
\hline Between Groups & 194.830 & 3 & 64.943 & 4.237 & .036 \\
Within Groups & 153.267 & 10 & 15.327 & & \\
Total & 348.096 & 13 & & & \\
\hline
\end{tabular}

Table 10 illustrates that there are statistically significant differences among the four grammatical cohesive subdevices across grade 3 high school EFL textbook $(F(3,10)=4.23, p=.036)$. As indicated in the table, $p$-value is less than alpha level $(\mathrm{p}<.05)$. In order to determine which specific groups differ, Tukey HSD test was used. 
Table 11. Multiple comparison of Tukey HSD Test between grammatical cohesive subdevices across grade 3 Iranian EFL high school textbook

\begin{tabular}{ccccc} 
(I) type of grammatical B & $(\mathrm{J})$ type of grammatical B & $\begin{array}{c}\text { Mean } \\
\text { Difference (I-J) }\end{array}$ & Std. Error & Sig. \\
& & & \\
\hline \multirow{2}{*}{ Reference } & Substitution & -9.53333 & 3.19653 & .056 \\
& Ellipsis & -4.05667 & 3.19653 & .601 \\
& Conjunction & -.30067 & 2.85906 & 1.000 \\
Substitution & Reference & 9.53333 & 3.19653 & .056 \\
& Ellipsis & 5.47667 & 3.19653 & .366 \\
& Conjunction & $9.23267^{*}$ & 2.85906 & $\mathbf{. 0 3 8}$ \\
Ellipsis & Reference & 4.05667 & 3.19653 & .601 \\
& Substitution & -5.47667 & 3.19653 & .366 \\
& Conjunction & 3.75600 & 2.85906 & .575 \\
Conjunction & Reference & .30067 & 2.85906 & 1.000 \\
& Substitution & $-9.23267^{*}$ & 2.85906 & $\mathbf{. 0 3 8}$ \\
& Ellipsis & -3.75600 & 2.85906 & .575 \\
\hline
\end{tabular}

Table 11 indicates that the differences between substitution and conjunction $(p=.038)$, and conjunction and substitution $(p=.038)$, are statistically significant $(p<.05)$.

Table 12 shows the descriptive statistics of the use of the grammatical cohesive subdevices across grade 4 high school EFL textbook.

Table 12. The results of the use of grammatical cohesive subdevices across grade 4 Iranian EFL high school textbook

\begin{tabular}{lcccc}
\hline & $\mathrm{N}$ & Mean & Std. Deviation & Std. Error \\
\hline Reference & 3 & .2603 & .18287 & .10558 \\
Substitution & 3 & 6.5667 & 5.68690 & 3.28333 \\
Ellipsis & 3 & 3.3333 & 2.99944 & 1.73173 \\
Conjunction & 5 & 1.1360 & 1.12609 & .50360 \\
Total & 14 & 2.5829 & 3.54927 & .94858 \\
\hline
\end{tabular}

Table 13 presents the results of ANOVA test:

Table 13. ANOVA results for grammatical cohesive subdevices across grade 4 Iranian EFL high school textbook

\begin{tabular}{cccccc}
\hline & Sum of Squares & Df & Mean Square & F & Sig. \\
\hline Between Groups & 75.951 & 3 & 25.317 & 2.883 & .089 \\
Within Groups & 87.814 & 10 & 8.781 & & \\
Total & 163.765 & 13 & & & \\
\hline
\end{tabular}

Table 13 illustrates that there are not statistically significant differences between four grammatical cohesive subdevices across grade 4 high school EFL text book $(F(3,10)=2.88, p=.89)$, since the $\mathrm{p}$-value is higher than our assumed alpha level $(p>.05)$.

The Chi-Square test was used to determine whether there are any significant differences among the frequencies of the subdevices of lexical cohesive devices. Table 14 shows the results of Chi-Square test in the frequencies of the use of lexical cohesive subdevices across grade 1 Iranian high school EFL textbook.

Table 14. Chi-Square results for lexical cohesive subdevices across grade 1 Iranian EFL high school textbook

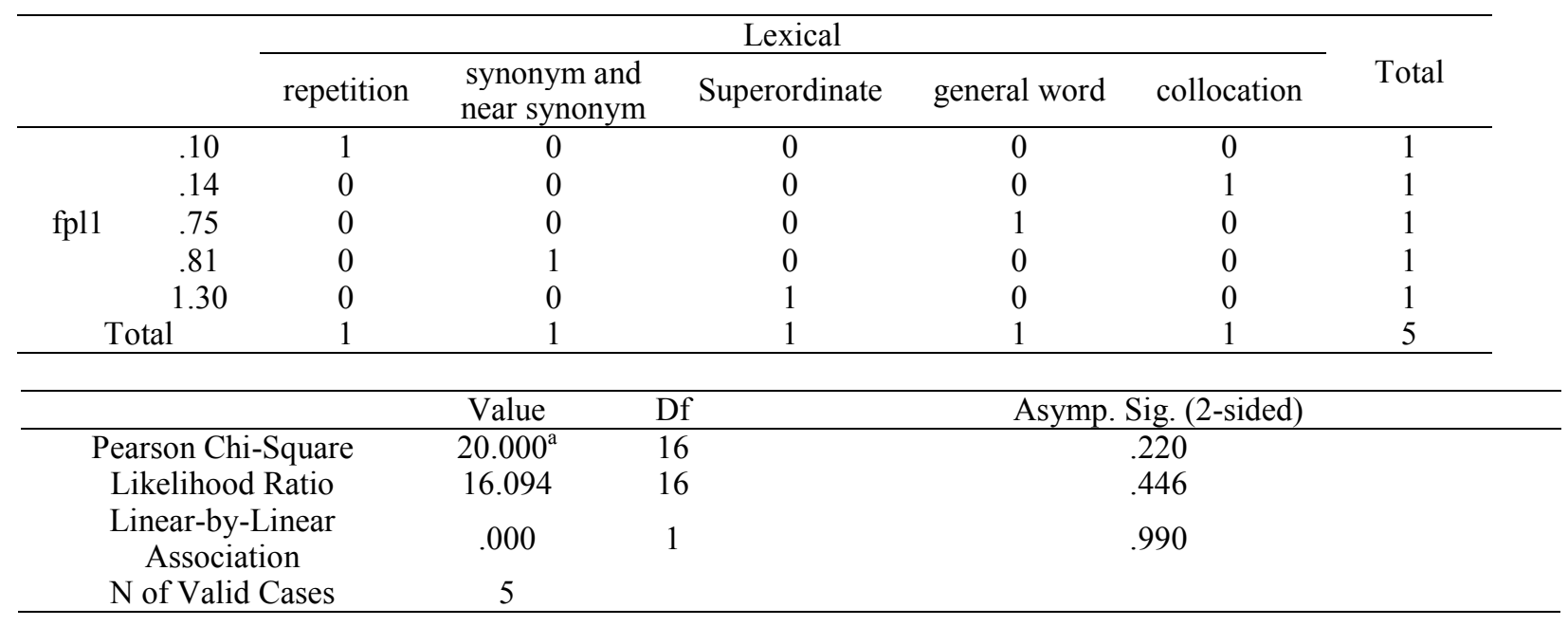


As can be seen by the frequencies cross tabulated in Table 14, there are not any significant differences among the 5 lexical cohesive devices across grade 1 EFL high school textbook $\left(x^{2}(16, N=5)=20, p=.22\right)$. As indicated in the table, the $p$-value is higher than the assumed alpha level $(p>.05)$.

Table 15 shows the results of Chi-Square test in the frequencies of the use of lexical cohesive subdevices across grade 2 Iranian high school EFL textbook.

Table 15. Chi-Square results for lexical cohesive subdevices across grade 2 Iranian EFL high school textbook

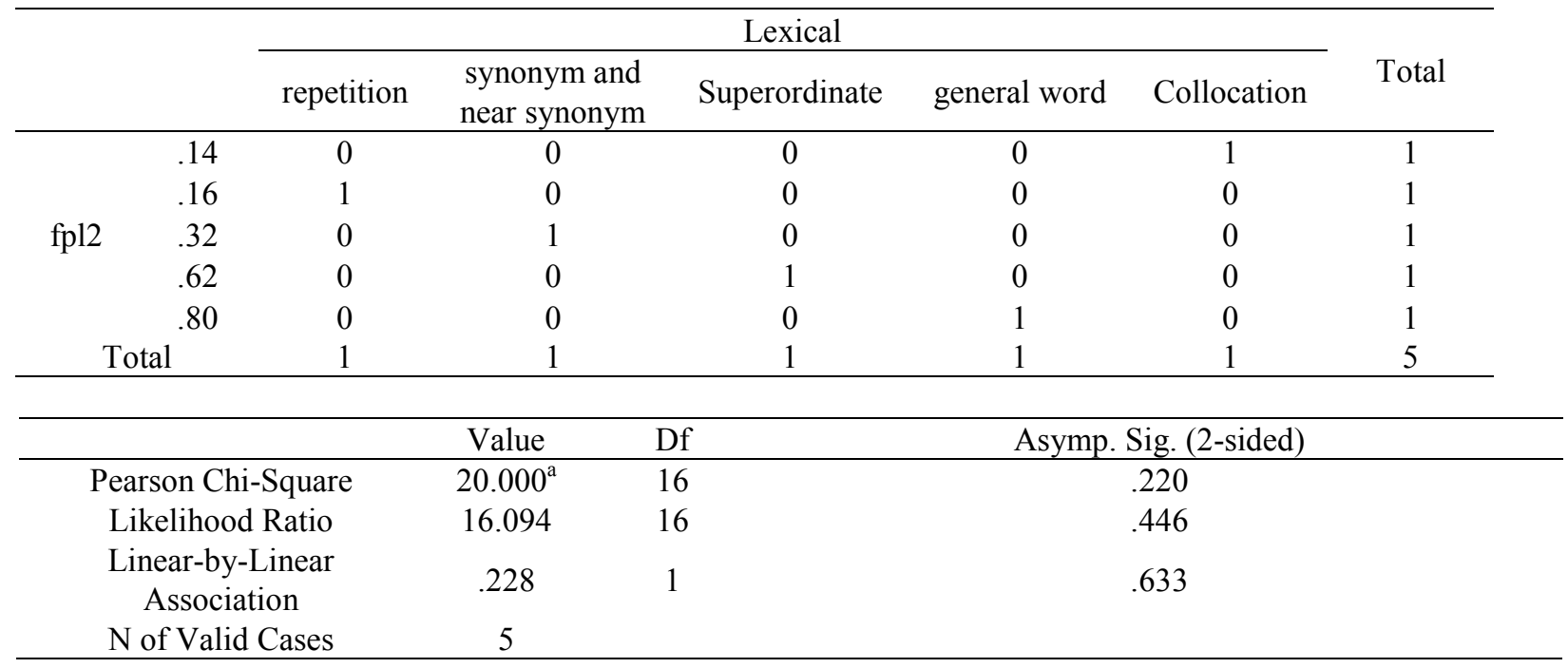

As can be seen in Table 15, there are not any significant differences among the 5 lexical cohesive devices in grade 2 EFL high school textbook $\left(x^{2}(16, N=5)=20, p=.22\right)$.

Table 16 shows the results of Chi-Square test in the frequencies of the use of lexical cohesive subdevices across grade 3 Iranian high school EFL textbook.

Table 16. Chi-Square results for lexical cohesive subdevices across grade 3 Iranian EFL high school textbook

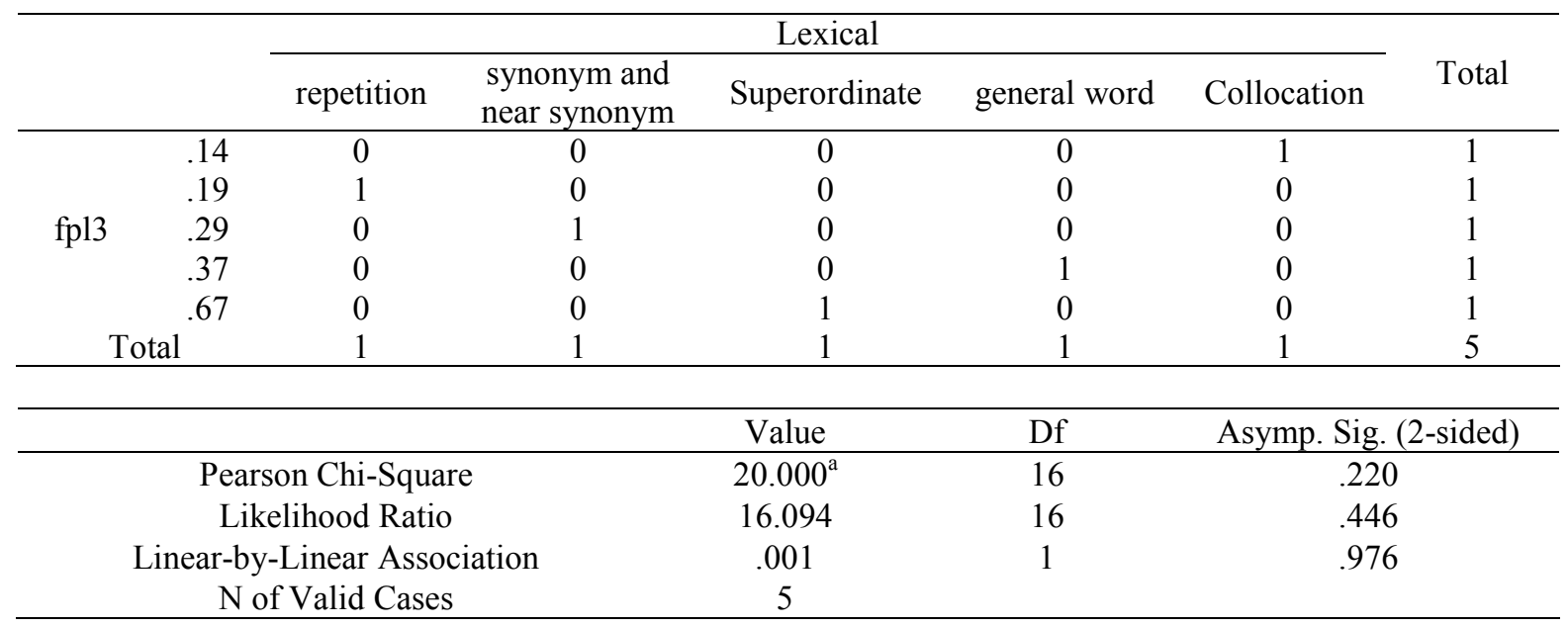

As shown in the table, there are not any significant differences among the 5 lexical cohesive devices in grade 3 EFL high school textbook $\left(x^{2}(16, N=5)=20, p=.22\right)$.

Table 17 presents the results of Chi-Square test in the frequencies of the use of lexical cohesive subdevices across grade 4 Iranian high school EFL textbook.

Table 17. Chi-Square results for lexical cohesive subdevices across grade 4 Iranian EFL high school textbook

\begin{tabular}{cccccccc}
\hline & \multicolumn{5}{c}{ Lexical } & \\
\cline { 2 - 6 } & repetition & $\begin{array}{c}\text { synonym and } \\
\text { near synonym }\end{array}$ & Superordinate & general word & Collocation & Total \\
\hline \multirow{4}{*}{ fp14 } & .10 & 1 & 0 & 0 & 0 & 0 & 1 \\
& .18 & 0 & 0 & 0 & 0 & 1 & 1 \\
& .39 & 0 & 1 & 0 & 1 & 0 & 2 \\
\multicolumn{2}{c}{ Total } & 0 & 0 & 1 & 0 & 0 & 1 \\
\hline
\end{tabular}




\begin{tabular}{cccc}
\hline & Value & Df & Asymp. Sig. (2-sided) \\
\hline Pearson Chi-Square & $15.000^{\mathrm{a}}$ & 12 & .241 \\
Likelihood Ratio & 13.322 & 12 & .346 \\
Linear-by-Linear Association & .005 & 1 & .943 \\
N of Valid Cases & 5 & & \\
\hline
\end{tabular}

As illustrated in the table, there are not any significant differences among the 5 lexical cohesive devices in grade 4 EFL high school textbook $\left(x^{2}(12, N=5)=15, p=.241\right)$.

The results of this study showed that although substitution is the most, and reference is the least frequent grammatical cohesive subdevice across each of the four EFL textbooks, but there are not significant differences among the four grammatical cohesive subdevices across grade 1 high school EFL textbook even across the pre-university EFL textbook. However, the present study revealed that there are significant differences among the four grammatical cohesive subdevices across grades 2 and 3 high school EFL textbooks. In addition, it was found that there are not any significant differences among the 5 lexical cohesive devices across each EFL high school textbooks. These findings indicate that there is inconsistency in these textbooks with respect to the use of grammatical and lexical cohesive subdiveces. As mentioned in the review of literature, Susilo (2010) emphasized the role of textbooks in teaching cohesive devices.

The findings of the present study further support the results of Talebinejad and Namdari's (2011) investigation of the reading comprehension sections of Iranian high school English textbooks in that they found differences among these textbooks with regard to the extent of using discourse markers.

In addition, Faghih Sabet, Khodabandehlou and Jahandar (2013) demonstrated that instruction on cohesive devices can improve EFL learners' reading comprehension. This finding is also emphasized by Pourdana, Naziri and Rajeski (2014) who suggested that textbooks containing frequent cohesive devices can have a significant role in improving EFL learners' reading comprehension ability at different proficiency levels. With regard to the studies just mentioned, what we found about the differences in the frequency of the usage of grammatical and lexical cohesive subdevices in the present study further highlights the demerits of Iranian EFL high school textbooks as to the infrequent distribution of cohesive devices in these textbooks. As the main focus of high school EFL textbooks in Iran is developing student's reading comprehension skills, with respect to these findings it can be concluded that grammatical and lexical cohesive subdevices have not been classified into a systematic order in the four Iranian EFL high school textbooks, and thus these textbooks are in need of substantial revision.

\section{Conclusion}

The present study aimed at investigating the frequency of the use of grammatical and lexical cohesive subdevices across each of the four Iranian EFL textbooks. To this end, the reading sections of each of the four textbooks were analyzed in terms of different grammatical and lexical cohesive subdevices. The findings revealed that substitution is the most frequent, and reference is the least frequent grammatical cohesive subdevice in all the four Iranian EFL high school textbooks. Accordingly, with regard to the results of One-way ANOVA $(p<.05)$ across each of the four Iranian EFL high school textbooks, the first null hypothesis of the study is partially rejected in that there are no significant differences among the frequencies of the grammatical cohesive subdevices across all the four EFL high school textbooks. Moreover, the results of Pearson Chi-Square demonstrated that the significant values of all the 5 lexical cohesive subdevices are higher than .05 across each of the Iranian EFL high school textbooks. Thus, the second null hypothesis of the study is confirmed in that there are no significant differences among the frequencies of the use of lexical cohesive subdevices across each Iranian EFL high school textbook.

The results of the present study can be beneficial for textbook authors and materials developers. Since, textbooks as significant instruments play a crucial role in Iranian students' education, knowing the weakness of these books can be beneficial for improvement of the quality of the four Iranian EFL high school textbooks.

Furthermore, the findings of this study can be fruitful for language teachers. The EFL instructors should notice the grammatical and lexical cohesive devices in the four Iranian EFL high school textbooks more carefully. School teachers have to pay attention to the proper distribution of cohesive devices in these textbooks and they can provide EFL students with more exercises on such devices.

In this study the researcher used the reading sections of Iranian EFL high school textbooks. For further studies this coverage can still be expanded to include more reading sections of English language textbooks taught in the institutes as well the books used for Iranian intermediate EFL learners. Accordingly, as this study was conducted on the grammatical and lexical cohesive devices across the four Iranian EFL high school textbooks, further research can be carried out in other English textbooks such as Top-Notch series, New Interchange series, New Parade series, American English File series, Connect series, Project series, and so on.

\section{References}

Aghagolzadeh, F. (2002). A comparison and criticism of discourse analysis and critical discourse analysis in text comprehension and production. (Unpublished Doctoral Dissertation). Tarbiat Modares University, Tehran.

Brown, H. D. (2001). Teaching by principles: An interactive approach to language pedagogy (2nd ed.). White Plains, NY: Longman. 
Dudley-Evans, T., \& St. John, M. (2005). Developments in English for specific purposes. Cambridge: Cambridge University Press.

Faghih Sabet, A., Khodabandehlou, M., \& Jahandar, S. (2013).The impact of instructing discourse markers (cohesive devices) on Iranian EFL learner's reading comprehension ability. Indian Journal of Fundamental and Applied Life Sciences, 3(3), 273-280.

Feez, S., \& Joyce, H. (2002). Text based syllabus design. Sydney: Macquire University.

Gholami, J., Ilghami, R., Molla Hossein,H., \& Tahoori, F. (2012). Cohesive devices in Iranian research papers across social sciences and medical sciences: the case of conjunctives in papers on biomedicine and applied linguistics. Iranian EFL Journal. 8(4), 294.

Halliday, M. K., \& Hassan, R. (1976). Cohesion in English. London: Longman.

McDonough, J., Shaw, C., \& Masuhara, H. (2013). Materials and methods in ELT. West Sussex: Willy-Blackwell Publishing Ltd.

Mogadam, L., \& Shabanipoor, M. (2013). Application of ellipsis and lexical cohesion in subtitling and dubbing: The case of prison break TV series. Journal of Foreign Language Teaching and Translation Studies, 2(2), 71.

Mohammadian, M. (2013). An investigation of lexical cohesion in Sadegh Choobak's stories. (Unpublished Master's Thesis). Islamic Azad University, Ahar.

Pourdana, N., Naziri, M., \& Rajeski, J. S. (2014).Cohesive devices frequency in English textbooks: Do they help or hinder EFL reading comprehension?. International Journal of Applied Linguistics \& English Literature, 3(4), 154-162. Rahi, M. (2012). A contrastive and comparative study of ellipsis in Persian and English. Mediterranean Journal of Humanities. 2(2), 213-218.

Richards, J. C., \& Renandya, W. A. (Eds.). (2002). Methodology in language teaching: An anthology of current practice. Cambridge: Cambridge University Press.

Roshan, B., \& Armioon, M. (2007). An investigation of Persian language cohesion in academic texts: the case of chemistry texts. In National Conference on Humanities. Tehran: Humanities and Cultural Sciences Research Center.

Susilo, N.(2010). The cohesion of recount texts in Look Ahead; English text book for 10th grade published by Erlangga.(Unpublished Master's Thesis). Retrieved June 16, from http://library.walisongo.ac.id/diglib/files/disk1/122/jtptiain-gdl-ernyrokhma-6070-1-skripsi-p.pdf.

Talebinezhad, M. R., \& Namdar, A. (2011). Discourse markers in high school English textbooks in Iran. Theory and Practice in Language Studies, 1 (11), 1590-1602. 